\title{
Strategies of blind children to achieve cognitive development. A qualitative study
}

Elsa I. Bei, Doctor of Psychology ${ }^{a}$, Alicia Oiberman, Doctor of Psychology ${ }^{a}$,
Daniela Teisseire, B.S. in Psychology and Jorgelina Barres, B.S. in Psychology

\section{ABSTRACT}

Introduction. Studying the cognitive development of blind children is particularly interesting in itself and because it provides intervention guidelines. The etiology of blindness is heterogeneous but this does not hinder the possibility of establishing the characteristics typical of its development. If these children acquire language at approximately 2 years, it means the last stage of sensorimotor intelligence has been achieved.

Objective. To determine the strategies that blind infants and toddlers adopt during the sensorimotor period to achieve an adequate level of development.

Population and method. The study was carried out in students from a public Special Education School of the Autonomous City of Buenos Aires. This was a qualitative study for theidentification of coincidences to define strategies. Blind children aged 3 months to 3 years were observed. The analysis unit was each significant segment of the "directed play" sessions conducted in a Gesell chamber and guided by the stimulation therapist.

Results. Thirty-four children were included and 55 observations were made. Children's "modes of action" were categorized as significant features of a strategy. Four thematic focuses and four stages were identified and chronologically supported with acquisitions that were considered "organizers." The assessment showed that 71\% of children achieved an adequate cognitive development for their age.

Conclusion. Systematizing strategies will help to develop an instrument to detect delays and define intervention guidelines.

Key words: infant, blindness, cognition, strategies, neurodevelopment.

Alicia Oiberman, M.D.: aoiberma@psi.uba.ar

Funding:

None

Conflict of interest:

None.

Received: 5-22-2017

Accepted: 10-19-2017
To cite: Bei E, Oiberman A, Teisseire D, et al. development. A qualitative study. Arch Argent Pediatr 2018;116(3):e378-e384.

\section{INTRODUCTION}

Studying the cognitive development of blind children is particularly interesting in itself and, additionally, it provides intervention guidelines. The World Health Organization $(\mathrm{WHO})^{1}$ considers a person to be blind if he/ she, even with adequate prescription glasses, has a visual acuity of $1 / 10$ on the Wecker scale in both eyes or if, with a better visual acuity, he/she has a visual field reduced to $35^{\circ}$ or less.

According to the Ministry of Health of Argentina, retinopathy of prematurity $(\mathrm{ROP})^{2}$ is the leading cause of blindness during childhood in Argentina, and this is the result of the high risks faced by preterm infants surviving in the neonatal intensive care unit.

Francesc Miñana has pointed out that the brain organization of blind infants and toddlers is different from that of sighted infants and toddlers, but this does not mean it is better or worse, only different. Brain imaging tests conducted in recent years have helped to confirm such differences. The studies by Rieser have clearly demonstrated a higher or different level of involvement of the occipital cortex in non-visual spatial exploration processing based on touch and hearing. The images obtained in blind people have shown that, from an early age, the visual cortex is recruited to participate in hearing and touch processing, and this is probably beneficial to perform hearing localizations, obtain information on obstacles, have a different sensitivity to music and language, process tactile information, facilitate Braille reading and object handling and perception. In addition, it has been determined that 
the different levels of occipital cortex recruitment for hearing or tactile information depend on experience.

Bei $^{5}$ corroborated that blind children whose parents provided a stimulating environment achieved a better cognitive development.

The working hypothesis was as follows: if blind children acquire language at approximately 2 years -just like sighted children-, it means that the last stage of sensorimotor intelligence has been achieved. The objective of this study was to determine the strategies adopted by blind children during the sensorimotor period to achieve an adequate level of development.

\section{MATERIAL AND METHODS}

This was a qualitative study. Design: Descriptive study with longitudinal and structured observation.

The study group was made up only of the students from the Early Stimulation Office of Special Education School 33 of the Autonomous City of Buenos Aires who attended the Gesell chamber session conducted by the Interdisciplinary Center for Research in Mathematical and Experimental Psychology (Centro Interdisciplinario de Investigaciones en Psicología Matemática y Experimental, CIIPME) - National Scientific and Technical Research Council (Consejo Nacional de Investigaciones Científicas y Técnicas, CONICET) between 2006 and 2015. The inclusion criterion was that children had to attend the Office, which meant being completely blind, given that there was another school for visually impaired children; the medical diagnosis submitted by parents was considered to determine the etiology of blindness. The exclusion criterion was having a neurological or other type of complication that affected cognitive development. The sample was not selected in a probabilistic fashion but using purposive sampling because it was determined by the nature of the subject matter under study, and it was self-selected because the mothers of invited children decided on their participation. The study was conducted by virtue of an agreement between the Government of the Autonomous City of Buenos Aires and CONICET. In relation to the sociocultural background of studied children, they attended the Early Stimulation Office of School 33, where students come from the Autonomous City of Buenos Aires and Greater Buenos Aires.
Their birth weight, gestational age, medical diagnosis, chronological and/or adjusted age, number of observations performed, and level of cognitive development achieved were recorded.

The analysis unit was each significant segment of the "directed play" sessions conducted in a Gesell chamber and guided by the stimulation therapist.

Direct observations were carried out in the presence of two passive observers, who recorded everything that happened, and two active observers, who proposed activities with playful material; all were members of the research team.

Once the session ended (approximately 6090 minutes), a written report was handed to the mother and a copy was sent to the school, which included stimulation guidelines, if necessary.

Each session was filmed so it was possible to watch the audiovisual material repeatedly to define categories and patterns in relation to the theoretical framework. These initial concepts and meanings guided observations and established relationships to restructure working areas. The "work diary" or "field log" included the notes taken during the session, each observer's personal impressions regarding the session, video reviews, and the description of the child's activity at school made by the stimulation therapist who was part of the team.

An initial categorization was done and codes were assigned to the child's "modes of action," which were taken as strategies. Such categories were grouped by topic and related to analysis units and thematic focuses. Topics were defined based on the different types of situations where the Argentine Scale of Sensorimotor Intelligence (Escala Argentina de Inteligencia Sensorio-motriz, EAIS) was used. Such situations were modified based on the needs observed in blind children.

A written informed consent to participate in the study and be filmed during the session was obtained from the parents of studied children.

The cognitive development assessment of blind children was done in accordance with the parameters of the EAIS ${ }^{6}$ and the Assessment Scale of Psychomotor Development (Escala de Evaluación del Desarrollo Psicomotor, EEDP) for children aged 0-24 months ${ }^{7}$ that could be applied to this population. To this end, certain EAIS tests and EEDP parameters were considered milestones achieved at a specific age. This is because no scale was available in Argentina for the assessment of development in blind children. 


\section{RESULTS}

Thirty four children who attended the Early Stimulation Office of the Santa Cecilia School participated in this study; their chronological age was 3-36 months and 12 of them had attended on several occasions. Three subjects were excluded; 1 was a deaf blind girl and the other 2 had been diagnosed with autism. All invited families agreed to participate.

Table 1 shows the data of children included in the sample and their medical diagnosis as per their school record.

Based on observations, the situations proposed for playful activities were modified, resulting in the following: object exploration, object searching, spatial orientation and location, and aids. Data were organized based on these thematic focuses. Element combination activities were the ones left out of the sessions with these children. Considering the advances in children's development until acquiring a mental representation, each of these aspects were analyzed and 4 stages were established: sensory exploration, which started with the child using his/her mouth during tactile exploration; acquisition of movement control, which entailed using the hands to identify objects; fine motor acquisition and discrimination, which started with the child using his/her fingertips to explore, and finally, acquisition of a mental representation, for which experiences became widespread and were recreated.

The stages were established chronologically according to the acquisitions that were considered "organizers," i.e., functioning structures that guided integration and that allowed accessing a more complex structure. ${ }^{8}$ In the first stage, the most relevant acquisition was mouth, foot, and hand exploration; in the second stage, hands at the midline and notion of space; in the third stage, awareness of body in relation to space; and in the fourth stage, generalization.

Thematic focuses, acquisitions, and stages are summarized in Table 2.

The cognitive strategies that were observed and systematized into sub-categories are described in Table 3.

In relation to object exploration, it is worth noting that haptic perception was used to establish size. Haptic perception is a different, more complete process than tactile or kinetic perception and, in this regard, it is worth noting the importance of voluntary activities and movement. These two elements are combined in this type of perception. It implies using touch in an active and purposeful manner to gather information from an object based on hand and finger activity.

The assessment of cognitive development was done based on the EAIS and EEDP parameters and showed that $71 \%$ of children had an adequate development for their age.

\section{DISCUSSION}

Results confirmed that $71 \%$ of studied blind children achieved an adequate cognitive development for their age in spite of their sensory disability.

Authors like Rosa and Ochaíta consider that blind individuals have the same resources as sighted people-except for sight-, and this results in the restructuring of cognitive development, skill acquisition, and information processing. They set out that blind children have a different phenomenological setting where touch, hearing, and smell are prominent and where language will become indispensable to understand the world and anything with which they cannot come in direct contact. ${ }^{5}$

During the first months of life of these children, motor skills are passive. This conditions their relationship with the environment; in some cases, it is even associated with a lack of motivation to move and, according to some authors like Burlingham, ${ }^{9}$ with inhibitions that may play a protective role. Prechtl, Cione, Einspieler, Bos, and Ferrari ${ }^{10}$ have pointed out that blindness may affect the vestibular system and have an impact on early motor development; therefore, children would display fidgetinglike movements for a longer period and the development of the proprioceptive system would be compensated.

Images obtained from positron emission tomography, functional magnetic resonance, transcranial magnetic resonance, and evoked potentials showed different levels of occipital cortex involvement to process tactile and haptic stimuli between congenitally blind subjects and blindfolded sighted subjects. The same procedure was used in relation to auditory information processing, spatial location, tactile recognition, and language comprehension. ${ }^{4}$

According to Piaget, a disadvantage of blind children is that they lack eye-hand-mouth coordination, which may lead to a developmental delay. However, such coordination -which triggers secondary circular reactions (Baldwin, ${ }^{11}$ 
Piaget ${ }^{12}$ ) - is replaced with ear-mouth-hand coordination.

Authors like Fraiberg ${ }^{13}$ and Bigelow ${ }^{14}$ have pointed out that the lack of eye-hand coordination entails the loss of action-stimulating elements and that the replacement of sight with auditory perception during the first months of life is relative because sound at this stage is not substantial. However, Ochaíta ${ }^{15-16}$ has stated that the delay pointed out by Fraiberg and Piaget in relation to representative function and symbolic play was the result of an inadequate stimulation. Nuñez ${ }^{9}$ has argued that motor delays -reflected in posture and self-initiated mobility and taking place in spite of the same level of neuromuscular maturity- would not occur if the infant was

TABLE 1. Sample information and level of development achieved. $N=34$ subjects

\begin{tabular}{|c|c|c|c|c|c|c|}
\hline $\begin{array}{l}\text { Subj. } \\
\text { observed }\end{array}$ & $\begin{array}{c}\text { No. of G } \\
\text { lobservations }\end{array}$ & $\begin{array}{l}\text { Gestational } \\
\text { ns age }\end{array}$ & $\begin{array}{l}\text { Birth } \\
\text { weight }\end{array}$ & $\begin{array}{l}\text { Diagnosis based on } \\
\text { school record }\end{array}$ & $\begin{array}{c}\text { Chronological } \\
\text { age }\end{array}$ & $\begin{array}{l}\text { Final } \\
\text { EAIS }\end{array}$ \\
\hline 1 & 3 & $27 \mathrm{w}$. & $1000 \mathrm{~g}$ & ROP stage $\mathrm{V}$ & $9 \mathrm{~m}$. , adjusted age & IV, adequate \\
\hline 2 & 1 & - & - & Bilateral atrophy & 36 m., adjusted age & Adequate \\
\hline 3 & 2 & $40 \mathrm{w}$. & - & Mesodermal dysgenesis & & \\
\hline & & & & of the anterior segment & $23 \mathrm{~m}$. & $\mathrm{V}$, insufficient \\
\hline 4 & 1 & $28 \mathrm{w}$. & $900 \mathrm{~g}$ & ROP stage V & $36 \mathrm{~m}$. & Insufficient \\
\hline 5 & 1 & $30 \mathrm{w}$. & $925 \mathrm{~g}$ & ROP, pulmonary dysplasia & 8 m., 5 d., adjusted age & Final III, adequate \\
\hline 6 & 2 & $40 \mathrm{w}$. & - & ROP stage $\mathrm{V}$ & $14 \mathrm{~m}$. & $\mathrm{V}$, adequate \\
\hline 7 & 5 & $28 \mathrm{w}$. & $1050 \mathrm{~g}$ & ROP stage $\mathrm{V}$ & 16 m., adjusted age & $\mathrm{V}$, adequate \\
\hline 8 & 4 & $34 \mathrm{w}$. & $2020 \mathrm{~g}$ & $\begin{array}{l}\text { Retinal detachment, } \\
\text { non-progressive cerebral atrophy }\end{array}$ & $11 \mathrm{~m}$. , adjusted age & IV, adequate \\
\hline 9 & 1 & $28 \mathrm{w}$. & $900 \mathrm{~g}$ & Turner syndrome & $36 \mathrm{~m}$. , adjusted age & $\begin{array}{l}\text { Adequate symbolic } \\
\text { function }\end{array}$ \\
\hline 10 & 3 & $28 \mathrm{w}$. & $880 \mathrm{~g}$ & Intracranial hemorrhage & 10 m., 22 d., adjusted age & Baseline VI, adequate \\
\hline 11 & 1 & $40 \mathrm{w}$. & $3850 \mathrm{~g}$ & $\begin{array}{c}\text { Septo-optic dysplasia, } \\
\text { hypothyroidism }\end{array}$ & $30 \mathrm{~m}$. & Baseline III, insufficient \\
\hline 12 & 1 & $38 \mathrm{w}$. & $2600 \mathrm{~g}$ & Nystagmus, gray optic disc & $14 \mathrm{~m}$. & Final $\mathrm{V}$, adequate \\
\hline 13 & 1 & $32 \mathrm{w}$. & $1420 \mathrm{~g}$ & ROP stage $\mathrm{V}$, amaurosis & 18 m., adjusted age & VI, adequate \\
\hline 14 & 2 & $40 \mathrm{w}$. & $3000 \mathrm{~g}$ & Bilateral ROP & $14 / 24 \mathrm{~m}$ & Final $V$, adequate \\
\hline 15 & 5 & $38 \mathrm{w}$. & $3290 \mathrm{~g}$ & Ptosis (eyelid) & $12 / 24 \mathrm{~m}$ & VI, adequate \\
\hline 16 & 2 & $32 \mathrm{w}$. & - & Myasthenia & $26 \mathrm{~m}$. & Final IV, insufficient \\
\hline 17 & 2 & $28 \mathrm{w}$. & $1260 \mathrm{~g}$ & ROP stage IV & $12 \mathrm{~m}$. , adjusted age & III, insufficient \\
\hline 18 & 1 & $30 \mathrm{w}$. & - & ROP stage IV & $27 \mathrm{~m}$. , adjusted age & VI, adequate \\
\hline 19 & 2 & $40 \mathrm{w}$. & $3740 \mathrm{~g}$ & Optic nerve hypoplasia & $27 / 30 \mathrm{~m}$ & VI, adequate \\
\hline 20 & 1 & $26 \mathrm{w}$. & $1050 \mathrm{~g}$ & ROP stage $\mathrm{V}$ & 18 m., 11 d., adjusted age & Baseline VI, adequate \\
\hline 21 & 1 & $40 \mathrm{w}$. & $3600 \mathrm{~g}$ & Optic nerve hypoplasia & $14 \mathrm{~m}$. & IV, insufficient \\
\hline 22 & 1 & $27 \mathrm{w}$. & $900 \mathrm{~g}$ & ROP stage $\mathrm{V}$ & $31 \mathrm{~m}$. , adjusted age & $\mathrm{V}$, insufficient \\
\hline 23 & 1 & $28 \mathrm{w}$. & $900 \mathrm{~g}$ & ROP stage $\mathrm{V}$ & $30 \mathrm{~m}$. , adjusted age & VI, adequate \\
\hline 24 & 3 & $40 \mathrm{w}$. & $3120 \mathrm{~g}$ & $\begin{array}{l}\text { Glioma of the optic chiasm, } \\
\text { brain tumor }\end{array}$ & $36 \mathrm{~m}$. & $\begin{array}{c}\text { Adequate representation } \\
\text { stage }\end{array}$ \\
\hline 25 & 1 & $37 \mathrm{w}$. & $2500 \mathrm{~g}$ & ROP stage III & $18 \mathrm{~m}$. & $\mathrm{V}$, adequate \\
\hline 26 & 1 & $41 \mathrm{w}$. & $3300 \mathrm{~g}$ & Bilateral hypoplasia & $17 \mathrm{~m}$. & Baseline VI, adequate \\
\hline 27 & 1 & $38 \mathrm{w}$. & $3500 \mathrm{~g}$ & Achondroplasia & $35 \mathrm{~m}$. & Final VI, adequate \\
\hline 28 & 1 & $40 \mathrm{w}$. & $3300 \mathrm{~g}$ & Genetic cause & $8 \mathrm{~m}$. & Baseline III, adequate \\
\hline 29 & 2 & $40 \mathrm{w}$. & $3900 \mathrm{~g}$ & Anophthalmia & $3 \mathrm{~m} . / 6 \mathrm{~m}$. & Adequate EEDP \\
\hline 30 & 1 & $40 \mathrm{w}$. & $3600 \mathrm{~g}$ & Glaucoma & $8 \mathrm{~m}$. & Baseline III, adequate \\
\hline 31 & 1 & $32 \mathrm{w}$. & $1900 \mathrm{~g}$ & ROP stage IV-V & 22 m., 17 d., adjusted age & Baseline $\mathrm{V}$, insufficient \\
\hline 32 & 1 & $36 \mathrm{w}$. & $2240 \mathrm{~g}$ & Corneal edema & $34 \mathrm{~m}$. & Insufficient-mov. control \\
\hline 33 & 1 & $37 \mathrm{w}$. & $2800 \mathrm{~g}$ & Unilateral microphthalmia & $19 \mathrm{~m}$. & $\mathrm{V}$, adequate \\
\hline 34 & 1 & $31 \mathrm{w}$. & $1690 \mathrm{~g}$ & ROP stage V & $28 \mathrm{~m}$. & Final V, insufficient \\
\hline
\end{tabular}

ROP: retinopathy of prematurity; w.: weeks old; g: grams; m.: months old; d.: days; EAIS: ArgentineScale of Sensorimotor Intelligence; EEDP: Assessment Scale of Psychomotor Development; mov.: movement. 
TABLE 2. Thematic focuses, stages, and acquisitions defined based on observations

\begin{tabular}{|c|c|c|c|c|}
\hline & $\begin{array}{c}\text { First stage } \\
\text { Sensory exploration }\end{array}$ & $\begin{array}{c}\text { Second stage } \\
\text { Acquisition of } \\
\text { movement control }\end{array}$ & $\begin{array}{c}\text { Third stage } \\
\text { Fine motor acquisition } \\
\text { and discrimination }\end{array}$ & $\begin{array}{l}\text { Fourth stage } \\
\text { Acquisition of } \\
\text { representation }\end{array}$ \\
\hline $\begin{array}{l}\text { A. Object } \\
\text { exploration }\end{array}$ & $\begin{array}{l}\text { 1. Object rotation using } \\
\text { the mouth. } \\
\text { Auditory } \\
\text { comprehension. }\end{array}$ & $\begin{array}{l}\text { 2. Object rotation using } \\
\text { the hands and recognizing } \\
\text { characteristics. } \\
\text { Continuous repetition of a } \\
\text { sound, sustained attention. }\end{array}$ & $\begin{array}{l}\text { 3. Exploration using the } \\
\text { fingertips. } \\
\text { Intentional sound } \\
\text { production: rhythms, } \\
\text { pauses. }\end{array}$ & $\begin{array}{l}\text { Mental representation of } \\
\text { an object; only one piece } \\
\text { of information (auditory, } \\
\text { tactile or olfactory } \\
\text { criterion) is enough to } \\
\text { recognize it. }\end{array}$ \\
\hline $\begin{array}{l}\text { B. Object } \\
\text { searching }\end{array}$ & $\begin{array}{l}\text { From "does not look } \\
\text { for it" to "looks for the } \\
\text { object based on touch } \\
\text { or sound." }\end{array}$ & $\begin{array}{l}\text { Looks for (tactile or auditory) } \\
\text { points of reference to find the } \\
\text { object or a part of it. }\end{array}$ & $\begin{array}{l}\text { Searches by removing } \\
\text { obstacles: } 1 \text {. touches every } \\
\text { object at the same time; } \\
2 . \text { touches every object } \\
\text { separately; } 3 \text {. separates } \\
\text { and rules out objects. }\end{array}$ & $\begin{array}{l}\text { Integration: space, } \\
\text { sound, and object. } \\
\text { Establishes associations } \\
\text { between different } \\
\text { elements. }\end{array}$ \\
\hline $\begin{array}{l}\text { C. Spatial } \\
\text { orientation and } \\
\text { location }\end{array}$ & $\begin{array}{l}\text { Midline precursor } \\
\text { spatial functions, } \\
\text { spatial exploration. }\end{array}$ & $\begin{array}{l}\text { Knowledge of close space } \\
\text { and distance and } \\
\text { retrieval game. } \\
\text { Auditory reception. }\end{array}$ & $\begin{array}{l}\text { Movement across the } \\
\text { space, positioning based } \\
\text { on sound. }\end{array}$ & $\begin{array}{l}\text { Mental representation } \\
\text { of space: combines the } \\
\text { information gathered } \\
\text { using the hands, mouth, } \\
\text { and ears. }\end{array}$ \\
\hline D. Aids & \multicolumn{2}{|c|}{$\begin{array}{l}\text { (Using external elements as aids). Not observed in } \\
\text { the first stages. }\end{array}$} & $\begin{array}{l}\text { Uses a tape to pull the } \\
\text { object or someone else's } \\
\text { hand. }\end{array}$ & $\begin{array}{l}\text { Uses elements to } \\
\text { support different body } \\
\text { parts and complete a } \\
\text { task. }\end{array}$ \\
\hline $\begin{array}{l}\text { E. Body } \\
\text { organizer }\end{array}$ & $\begin{array}{l}\text { Mouth, foot, and hand } \\
\text { used for exploration. }\end{array}$ & $\begin{array}{l}\text { Hands at the midline } \\
\text { and notion of space.. }\end{array}$ & $\begin{array}{l}\text { Awareness of body in } \\
\text { relation to space. }\end{array}$ & $\begin{array}{l}\text { Integration, } \\
\text { generalization. } \\
\text { Experience recreation. }\end{array}$ \\
\hline
\end{tabular}

TABLE 3. Cognitive strategies observed among blind infants and toddlers

\begin{tabular}{|c|c|c|c|}
\hline Object exploration & Object searching & Spatial orientation and location & Aids: used to grab an object \\
\hline Sucking. & Touching. & Midline. & Tape. \\
\hline Touching. & $\begin{array}{l}\text { Feeling with the hands } \\
\text { and feet }\end{array}$ & $\begin{array}{l}\text { Scanning with the arms and legs: } \\
\text { horizontal plane. }\end{array}$ & Stick. \\
\hline Pushing. & $\begin{array}{l}\text { Horizontal scanning } \\
\text { with the arms. }\end{array}$ & $\begin{array}{l}\text { Reaching out the arms: } \\
\text { perpendicular plane. }\end{array}$ & Mother's hand. \\
\hline Pressing down. & Making vibrations to locate an object. & Throwing objects. & $\begin{array}{l}\text { The body itself } \\
\text { (precursor of the white cane). }\end{array}$ \\
\hline Rubbing. & Locating based on sound. & Moving across the space. & $\begin{array}{l}\text { Using the mouth as an aid } \\
\text { or point of reference. }\end{array}$ \\
\hline $\begin{array}{l}\text { Feeling the } \\
\text { weight of objects. }\end{array}$ & $\begin{array}{l}\text { Locating an object based } \\
\text { on a point of reference. }\end{array}$ & Pausing to catch a sound. & \\
\hline Scraping. & $\begin{array}{l}\text { Looking for embossing, edges, } \\
\text { surfaces, textures. Feeling the } \\
\text { temperature with the hands and feet. }\end{array}$ & Distance and retrieval game. & \\
\hline Shaking. & $\begin{array}{l}\text { Recognizing the presence of } \\
\text { obstacles that have to be removed. }\end{array}$ & Points of reference. & \\
\hline Crossing the space. & $\begin{array}{l}\text { Searching in the last } \\
\text { successful place. }\end{array}$ & \multicolumn{2}{|c|}{$\begin{array}{l}\text { Using both hands to position him/herself } \\
\text { in space by integrating the information. }\end{array}$} \\
\hline $\begin{array}{l}\text { Going around the space } \\
\text { in an analytical manner. }\end{array}$ & $\begin{array}{l}\text { Acquiring the mental } \\
\text { representation of an object. }\end{array}$ & \multicolumn{2}{|l|}{$\begin{array}{l}\text { Looking for a limit or boundary } \\
\text { based on his/her own body. }\end{array}$} \\
\hline $\begin{array}{l}\text { Looking for } \\
\text { points of reference. }\end{array}$ & $\begin{array}{l}\text { Notion of space (up, behind, in front) } \\
\text { based on his / her own body. }\end{array}$ & $\begin{array}{l}\text { Acquiring dimension based } \\
\text { on haptic perception. }\end{array}$ & \\
\hline
\end{tabular}


adequately stimulated. Following Piaget, different authors have described an important delay of 8-36 months compared to sighed children in the object and people representation stage. According to Nuñez, such delay in the acquisition of representation may be the consequence of a poor interaction with the mother. This interaction, which facilitates representation, may be similar to Vigotsky'stool mediation concept, i.e., the possibility a blind person has of using someone else's experience as a tool to "see".

This study has demonstrated that blind children establish schemes of action to recognize and look for objects in the preverbal period, even if such mechanisms are different and they use other strategies.

Future studies should further analyze the evolutionary patterns of blind children to examine the strategies and resources they adopt to gain knowledge and orient and position themselves in space, so as to establish how they acquire mental representations.

The general concepts that supported the foundation of this study were based on our own experience and the theoretical framework, and were specified, consolidated or corrected during the study and, at the same time, guided the study plan. The initial hypothesis was to adapt the EAIS to blind children because it was believed that the scale materials could not be used in this population. Based on the study, it was possible to determine that many tests and playful materials could actually be used. It may be stated that the EAIS parameters are the same as for sighed children and that the difference lies in the stimuli required by blind children. All studied children attended the Early Stimulation Office so it is assumed that they received the adequate specific stimulation. In addition, working with parents in the Gesell chamber was "salutogenic" because it was possible for them to focus on what their children could do instead of what they lacked.

Braslavsky ${ }^{17}$ has argued that, according to Vigotsky, sensory deficits should not be considered a strictly biological problem but should also be approached as a social problem. For humans, sight and hearing are cultural instruments and, if one of these senses fails, the social functions related to it may be compensated; in the case of blind people, such compensation takes place based on touch, which grants them access to the cultural world using Braille. The importance lies in meaning, not in the signs used to access it.
A sensory deficit should not affect children's development as long as they live in conditions that promote their normal growth. Language development, which is critical for blind children to understand the world around them, is not hindered by lack of sight and, if guided by adults, children may associate every word with the object they are exploring. At the age of studied children, they communicate with their mothers by means of vocalizations; therefore, it is necessary for mothers to interpret the different behaviors of their babies since their early life and thus create a meaningful dialog. These findings will help to provide a better health care for these children and allow to eradicate prejudices that hinder us from seeing the possibilities blind children have in spite of their sensory disability.

\section{CONCLUSION}

Seventy-one percent of children achieved an adequate cognitive development for their age using strategies that, if systematized, would help to develop a tool to detect delays and define intervention guidelines. Developmental parameters in blind children may be the same as those observed in sighted children, and the difference may lie in the stimuli they require.

\section{REFERENCES}

1. Organización Mundial dela Salud. Ceguera y Discapacidad visual. [Accessed on: October 25th, 2017]. Available at: www.who.int/mediacentre/factsheets/fs282/es/.

2. Argentina. Ministerio de Salud de la Nación. Prevención de la ceguera en la infancia por retinopatía del prematuro (ROP). Resolución Secretarial N.o 26/03 de mayo de 2003. [Accessed on: October 25th, 2017]. Available at: http: / / www.msal.gob.ar/images / stories / bes / graficos /0000000178cnt-n04-libro-rop.pdf.

3. Miñana F. Presentación. In: Leonhardt M. La intervención en los primeros años de vida del niño ciego y de baja visión. Un enfoque desde la atención temprana. Madrid: Organización Nacional de Ciegos de España; 2002.P.13-5.

4. Rieser J. Theory and Issues in Research on Blindness and Brain Plasticity. In: Rieser J, Achmead D, Ebner F, et al. Blindness and Brain Plasticity in Navigation and Object Perception. New York: Lawrence Erlbaum Associates, 2008.P.3-19.

5. Bei EI. Efectos de la estimulación y el vínculo afectivo en el desarrollo sensorio-motor y cognitivo de los bebés no videntes [Dissertation]. Buenos Aires: Universidad Católica Argentina; 2015. [Accessed on: October 25th, 2017]. Available at: http:/ / bibliotecadigital.uca.edu.ar/ repositorio/tesis/efectos-estimulacion-vinculo-afectivo.

6. Oiberman A, Mansilla M, Orellana L. Nacer y Pensar Construcción de la Escala Argentina de Inteligencia Sensorio-motriz (EAIS) de 6 meses a 2 años. Buenos Aires: Ciipme-Conicet; 2002.

7. Rodríguez S, Arancibia V, Undurraga G. Escala de Evaluación del Desarrollo Psicomotor de 0 a 24 meses (EEDP). Santiago de Chile: Galdóc; 1979. 
e384 / Arch Argent Pediatr 2018;116(3):e378-e384 / Original article

8. Spitz RA. El primer año de vida del niño. Buenos Aires: Fondo de Cultura Económica; 2013.

9. Nuñez A. Desarrollo psicológico del niño ciego. In: Checa F, Marcos M, Martín M, et al. Aspectos evolutivos de la deficiencia visual. Madrid: ONCE; 1999.P.1-39.

10. Prechtl HF, Cioni G, Einspieler C, et al. Role of vision on early motor development: lessons from the blind. Dev Med Child Neurol 2001;43(3):198-201.

11. Baldwin JM. Mental Development in the Child and the Race. $3^{\text {rd }}$ ed. New York: Mcmillan; 1906.

12. Piaget J. El nacimiento de la inteligencia en el niño. Neuschâtel: Delachaux et Niestlé; 1963.
13. Fraiberg S. Niños ciegos. Madrid: Instituto Nacional de Servicios Sociales; 1982.

14. Bigelow AE. The development of joint attention in blind infants. Dev Psychopathol 2003;15(2):259-75.

15. Ochaíta E. Unaaplicación de la teoríapiagetiana al estudio del conocimiento espacial en niños ciegos. Infanc Aprendiz 1984;25:81-104.

16. Ochaíta E. Ceguera y desarrollo psicológico. In: Rosa A, Ochaíta E, edts. Psicología de la ceguera. Madrid: Alianza; 1993.P.111-202.

17. Braslavsky B. Dossier. El ciego en la teoría de Vigotsky. Discapacidad visual hoy. 1999;5(7):17-24. 